\title{
The Guardian of Ninety Million Stomachs
}

\section{Dr. Harvey W. Wiley of the Bureau of Chemistry \\ By William Atherton Du Puy}

B ECAUSE one man saw a great light, because he B was a great scientist, a great politician, a great philosopher, a great fighter, a great publicity agent. he nin lived and fought, the babies of a nation are no longer drugged into degeneracy and death. Because of his activities the adults of a nation are no longer un knowingly acquiring drug habits that sap their vitality. Because of the standard his influence has set in the matter of pure foods and drugs a new spirit is in the matter of phe foods and drus to put all lines abros a hasis of honesty that they have

of business on a

For Dr. Harvey W. Wiley, chief chemist of the Department of Agriculture, has so wrought as to bring to bear upon the every day live of all the people an influence among the greatest of any man of his time. He has a theory that the man of to-morrow is a product of what goes into his stomach to-day. He set out long ago to make better men through giving them better food and preventing the injuries that were being done them through deceptive drugs. He has enthem the stupendous difficulties.

And now, suddenly, his enemies execute a coup that was intended to prove his undoing. $\mathrm{He}$ is charged with irregularity in the employment of a necessary expert at a salary of $\$ 1,600$ a year. It is recommended that because of this alleged irregularity all the accomplishments of his thirty years of labor be set aside and that he be summarily dismissed.

But the ninety million have insisted on being heard from. They have arisen en masse and have used every organ at their disposal in voicing their displeasure at the proposal to remove the pure food expert. There never was a salary of $\$ 1,000$ paid to an expert, legitimate or otherwise, that so aroused a nation or promised so many embarrassments to men high in public life.

All this calls particular attention to Dr. Wiley, whose activities have been a matter of comment for a quarter of a century, whose personality has given him a position that is unique, yet whose enemies, though few, are powerful, for the money of all the illicit business he has disturbed is back of hem.

Dr. Wiley is an interesting character. His father was an Indiana farmer of Scotch descent who mastered Greek unaided and preached thirty years without pay. His preached thirty years without pay. His
son grew up on a farm and became the son grew up on a farm and became the
champion corn planter of the neighborhood. $\mathrm{He}$ paid his way through Hanover College with money he earned doing manual labor on the farm. Later he taught and saved money for a year at Harvard, then taught t Purdue. He became State Chemist in Indiana and in 1882 investigated maple Indiana and in 1882 investigated maple
sugar adulterations, one of the first food investigations the United States knew. The following year he was made chief chemist of the Department of Agriculture, a position so obscure that its only duty was passing upon the mixture of fertilizers. This was twenty-eight years ago and with the growth of the Bureau of Chemistry from fertilizer mixing to of the Bureau of Chemistry from fertilizer mixing to
the supervision of the foods and drugs of a nation has the supervision of the foods and drugs of a nation has
been the growth of Wiley, for he has been the Bureau of Chemistry.

Dr. Wiley is now a man of sixty-eight years of age, a great, hulking man, six feet tall, weighing 220 pounds, in perfect health and apparently twenty year.s vounger than he is.

Soon after Dr. Wiley became associated with the Department of Agriculture he began his pure food investigations. In Indiana had been born an ambition which was nothing less than giving the people of the nation honest food. Everywhere there was deception in the things that were sold. If one bought pepper it was eighty per cent ground up shells. If one bought meat it was "embalmed." If one bought fruit it was pickled in injurious chemicals. If one bought proprietary medicine it might have any amount of opiates in it without his knowledge. There was no dependence to be placed in labels and names.

Wherever money was to be made through deception, deception was being practiced. The whole people bought, as food, substances with lit le nourishment in them. More than that, they were being deceived into putting things into their stomachs that were cryingly injurious to them.

The people did not know this. They were busy with other things and little interested in being told. Even when convinced they did not know what to do about it. They had to be informed, interested, and led to act. It is no mean task to lead the public throug these stages. But Dr. Wiley was the man with the particular qualities to accomplish these things. In in the thoroughly aroused over the food question. In the second place he was willing to

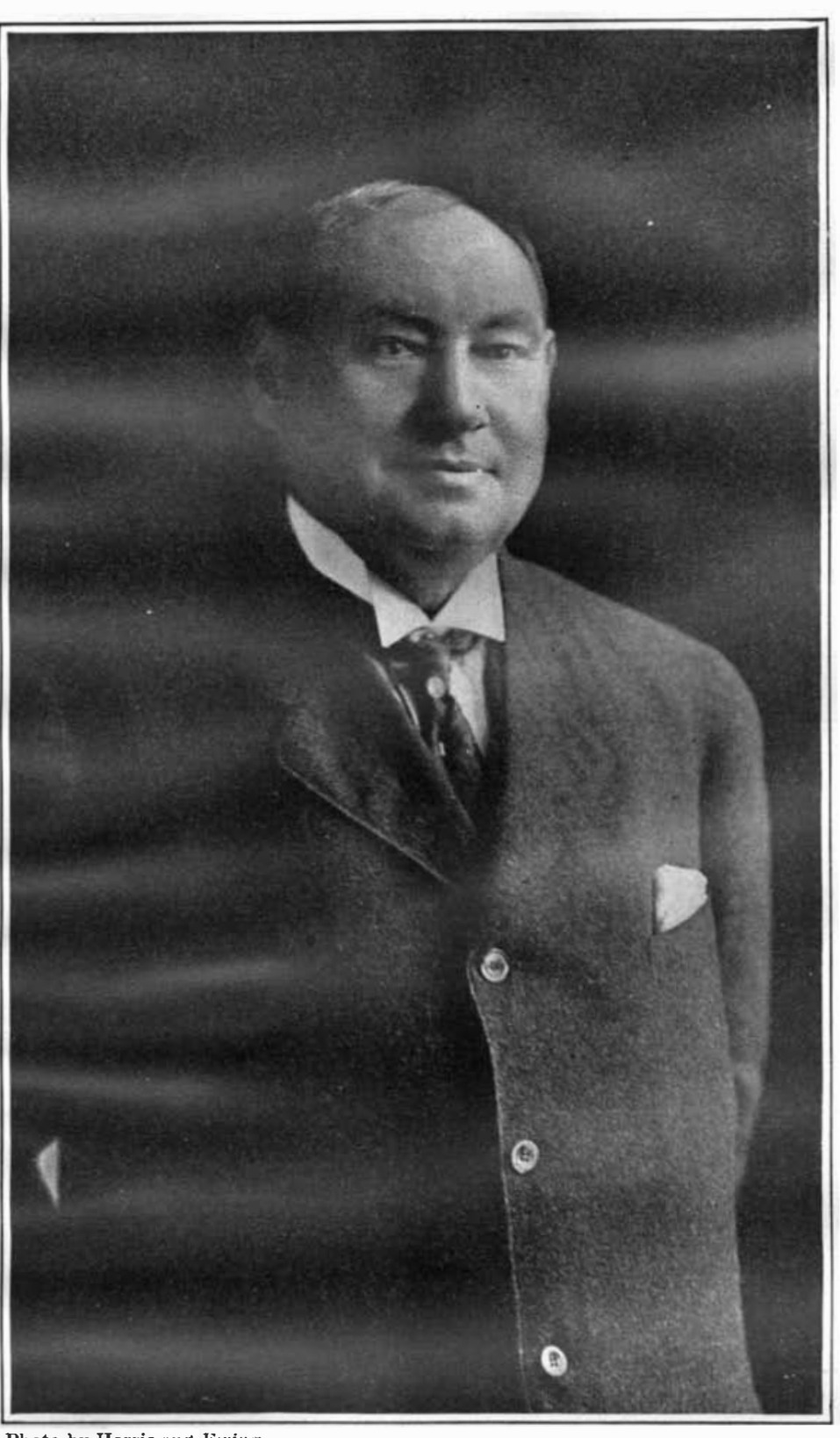

DR, HARVEY W. WILEY

chief of the Bureau of Chemistry of the Department of Agriculture.

operation under the guidance of the chief of the Bureau of Chemistry on January 1si, 1907.

But with the passage of the law the troubles of the chief chemist were but just begun. Previously his campaign had merely been educational. Now it was administrative. The blacklisting of a given drug or a given food meant the antagonizing of the interests back of that food or drug. Millions had been made in the manufacture of patent medicines that made their reputations for cures by the soothing effects of the opiates they contained. Those millions were to be destroyed by the prohibitions of Wiley. Other millions were being made in an adulteration of various foodstuffs and by their preservation with injurious foodstuffs and by their preservation with injuriuse of dyes and coloring matters. Fortunes were made by branding an inferior article as something better. In the aggregate it is estimated that $\$ 400,000,000$ in invested capital was arrayed against this one man. That capital was determined to destroy him. His position was political. Big money is prominent in politics. It has long played politics in an attempt to get rid of Wiley. A trial involving the use of a food pre servative was recently held in Indianapolis. Dr. Wiley was refused permission to go to Indianapolis to testify. The court sent a committee to Washington to get his affidavit.

"Do you realize," Dr. Wiley was asked, "that the defendants in this case represent an investment of $\$ 10,000,000$ ?'

"Probably so," responded the chief chemist, "but if there was at stake the life of but one baby instead of thousands, I would place that life above the interest of the capital invested."

The Wonderful Mechanism of the

\section{Watch}

$\mathbf{F}^{\mathrm{EW}}$ pieces of machinery show more F marvelous features than that of the watch. As a general proposition it may be stated that a watch is the smallest, most delicate instrument of the same number of parts that has ever been devised. About one hundred and seventy-five different pieces of material enter into its construc tion, and upward of twenty-four hundred separate operations are comprised in its manufacture.

Certain of the facts connected with its performance are almost incredible, when considered as a whole. A blacksmith strikes several hundred blows on his anvil in a day and, as a matter of course, is glad when Sunday comes; but the roller jewel of a watch makes every day-and day after day $-432,000$ impacis against the fork, or 157,680,000 blows during the course of a year, without stop or rest-or some $3,153,600,000$ blows during the space of twenty years, the period for which a watch is usually guaranteed to keep good time.

But the wonder of it does not cease here. It has been calculated that the power that

work night and day, year after year, on this one job. In the third place he had the happiest faculty of the publicity

Dr. Wiley's greatest asset in his campaign for pure foods has been his ability to get into the papers. He is the most sociable man on earth. He is an artist as an after-dinner speaker. $\mathrm{He}$ is a clubman. $\mathrm{H}$ accepts many invitations, especially where there is a chance to make an after dinner speech. Then he talks for the newspapers chiefly about pure food. $\mathrm{He}$ has the gift of talking in headlines. There is an epigramatic sensation in every one of his speeches. He always makes a "story" that gets on the front page, a "story" that calls public attention to some food abuse. The same is true when he talks to reporters. There is not a newspaper man in Washington who does not fall back on Dr. Wiley whenever he has failed to get something to write elsewhere. It was through publicity that he finally got his message to the masses. They came to know the dangers that beset them through the food they ate, and they came to understand the possibilities of removing these dangers. The campaign of publicity finally ended in the passage of the Pure Food and Drug Act of 1906, which was put in moves the watch is equivalent to only four times the force used in a flea's jump. The watch-power is, therefore, what might be termed the equivalent of a four flea-power. One horse-power would suffice to operate $270,000,000$ watches.

Furthermore, the balance-wheel of a watch is moved by this four flea-power one and forty-three one-hundredths inches with each vibration, or $3,5583 / 4$ miles continuously in one year.

Not much oil is required to lubricate the little machine on its 3,500-mile run. It takes only one-tenth of a drop of oil to oil the entire machinery of a year's service.

\section{Lung Capacity as Affected by Corset-wearing} THE lung capacity of the average woman who 1 does not wear corsets is about 2800 cubic centimeters or 171 cubic inches; of one who is in the habit of wearing corsets only 2,200 cubic centimeters or 134 cubic inches; so that the capacity of the normal and unrestricted lungs is about 27.3 per cent more than that of those which have been compressed by the corset. 